\title{
Selected Ecological Factors and Social Responsibility of Agribusiness Enterprises from Pomorskie Province
}

\author{
Izabela WIELEWSKA \\ UTP University of Science and Technology, Bydgoszcz, Poland \\ wielewskalutp.edu.pl
}

\begin{abstract}
The aim of the article is to present the issues of social responsibility of agribusiness enterprises in the Pomorskie region in terms of their ecological responsibility, indication of selected pro-ecological factors and determination of the relationship between them and the competitiveness of the surveyed companies. The T-Chuprov convergence coefficient was used to test the significance and strength of the correlation compound. Its significance was examined on the basis of the $\mathrm{ch}^{2}$ test.

Economic activity, which is a source of many threats to the environment and human health, should be carried out in such a way that it uses and shapes the natural environment in a sustainable way, while sustaining the durability of natural resources. Economic entities have to pay more and more attention to the impact of their production processes on the environment and human health.

It should be noted that more and more enterprises take responsibility for the effects of their actions on the natural environment and significantly contribute to its improvement. Thanks to this, they achieve measurable benefits. Research on the ecological aspect of CSR showed that the correlation relationship between the selected pro-ecological factors and the competitiveness of the surveyed companies is significant and the strength of the relationship is weak. Many factors contribute to the competitive advantage of Pomorskie's enterprises on the market, including those that relate to the environmental aspect of CSR.

The concept of corporate social responsibility consistently implemented by enterprises can contribute to improving competitiveness and building a lasting advantage over competitors.
\end{abstract}

Keywords: Ecological Factors, Corporate Social Responsibility, Competitiveness of Enterprises.

\section{$1 \quad$ Introduction}

In a dynamically developing market economy, there is a growing interest in the issues of corporate social responsibility (CSR), consisting of a conscious activity oriented not only on economic aspects, but also on broadly understood social and environmental interests.

On the European soil, CSR (its definition contained in the Green Book) is defined as voluntary inclusion of social and ecological aspects by the company while 
conducting trade activities and contacts with stakeholders. Social responsibility is an element of building a long-term development strategy of the company [14].

Nowadays attention is paid to the need for responsibility for all the company decisions and undertakings that affect not only owners, managers, employees and shareholders, but also customers and other entities that the company influences.

Until recently, many companies carried out their activities in accordance with the theory of M. Friedman, according to which the basic goal of the company's activity is profit. However, the increase in social expectations has changed the current model of business thinking. More and more enterprises have begun to perceive and implement social and ecological activities, treating the environment as a kind of stakeholder in implementing the concept of corporate social responsibility [10], mainly because the economic sector is most frequently accused of environmental degradation, economic scandals and activities targeted only to maximize income without being responsible for the consequences of their actions [9].

The subject scope of corporate social responsibility includes, among others: the compliance with legal norms, philanthropy and the development of the local community, environmental protection, sustainable development, animal rights, human rights, employee rights, market relations, corruption and corporate governance [2].

The aim of the article is to present the issues of corporate social responsibility in terms of their ecological responsibility, to indicate selected pro-ecological factors and to determine the relationship between them and the competitiveness of the surveyed companies.

\section{Ecology in the Concept of CSR - a Theoretical Aspect}

The increasing human interference in the natural environment and the subjugation of nature on a global scale result in negative consequences and the increasing ecological crisis, which means the inability to maintain human activity within limits safe for man and nature. This mainly applies to the activities of enterprises. The response of economic circles to the needs of the modern gave rise to the concept of Corporate Social Responsibility (CSR) in the 1990s [6]. An important feature of this concept is its interdisciplinary nature which shows the need for integration and knowledge in various fields of science and business practice [13].

Corporate social responsibility is not clearly defined, either in the subject literature or in practical activity. There are different interpretations of CSR in various fields of interest, and a clear evolution of the interpretation of this concept is noticed. It is worth noting the definition of this issue from the point of view of the motives of business entities implementing this idea $[4,10]$. In the opinion of the entities, compliance with the rules can be understood as voluntary, pro publico bono activity or as a legal obligation resulting, for example, from environmental protection regulations or a comparison of profit and loss in the light of their own activities [14, 15].

Corporate social responsibility in business entities includes the following areas [14]:

- Market environment (suppliers, recipients, partners, competitors) - here, the expression of CSR is the application of ethics in dealing with the environment, the 
use of honest information and advertising, the implementation of appropriate rules in the privatization processes, mergers and take-overs.

- Public environment (public administration, public benefit institutions, social organizations, residents) - CSR is a project carried out by economic entities for science, education, culture, health care, sport, in the forms of patronage, sponsorship, private and public partnership and other types of cooperation between enterprises and the public, including employee volunteering.

- The sphere of employment: human resources management (recruitment, selection, motivation system, remuneration), resolving employee conflicts, especially in the supervisor-subordinate relationship - CSR means adherence to the principle of subjectivity of employees in the human resources management in an enterprise, social justice, opportunities for personal development, guarantee of a sense of stability and security.

- Environmental protection (technology and organization of all enterprise activities related to the use of environmental resources); CSR is the proper management of natural resources in the enterprise, proper evaluation of resource use, compliance with environmental protection regulations.

- Investor relations (with existing or potential shareholders); CSR means reliability and full information for investors, respect for pre-emption rights, and compliance with promises made.

Compliance with the principles of responsible business first became popular where consumers began to demand high-quality goods, i.e. goods that are manufactured with regard for the natural environment, while respecting workers' rights and maintaining ethical standards. Thus, conduct in line with CSR principles, may be a source of competitive advantage in the markets.

The International Organization for Standardization has developed the ISO 26000 standard in the field of corporate social responsibility (in Poland PN-ISO 26000). Corporate social responsibility was defined as: the responsibility of the organization for the effects of decisions and actions taken towards the public and the environment. This responsibility is implemented through transparent and ethical behaviours that:

- contribute to sustainable development, health and social well-being,

- comply with applicable laws and international standards of behavior;

- take into account the expectations of stakeholders;

- are integrated throughout the organization and practiced in its internal and external relations [5].

As part of the implementation of the CSR concept, ecological responsibility primarily refers to the reduction of negative environmental effects, in particular to manufacturing products from environmentally friendly materials, savings in energy, water and materials in the production process, using recycling of raw materials and products, introduction of environmental assessments or reports on environmental activities [9]. The basic task of enterprises in taking care of the environment is to reduce resource consumption and pollution emissions, to recycle, and to develop environmentally friendly technologies [13]. 
A significant interest in ecological responsibility results from several premises [1]:

- the environmental aspect is a factor in the development of the enterprise,

- the problem of environmental protection has a global dimension,

- the environmental aspect may be a key factor for market success,

- the ecological factor plays a role in the processes of internationalization of enterprises,

- the ecological factor influences the implementation of local strategies by the company,

- the ecological factor may have an impact on the diversification phenomena of corporations, including internal ones.

Ecological CSR activities are related to ecology:

- environmentally-friendly production method, which in terms of competition allows to reduce energy and material consumption, or reduce fees and environmental taxes,

- a distribution method that ensures the use of the same channels for the recovery and recycling of waste and post-consumer waste,

- the product itself, which is characterized by environmentally friendly features, such as mitigation of global warming, efficient use of natural resources and proper disposal of chemical substances [12].

Ecological activities in the field of CSR lead to an increase in the trust of stakeholders, and, as a result, to create the reputation of the company.

Corporate social responsibility refers to the following expectations of society towards an organization at a given time:

- economic - through the production and manufacture of goods, satisfying the needs of clients and services, unemployment countermeasures, creating an additional financial result;

- legal - the company pursues its economic goals in compliance with applicable law;

- ethical - the company identifies itself with existing and widely accepted norms and values that apply in a given environment.

- philanthropic - undertaking voluntary activities for the people employed in the company, as well as for the environment and society [3]. 
Table 1. Arguments for and against corporate social responsibility [7].

\begin{tabular}{|c|c|}
\hline Arguments in favour of social responsibility & Arguments against social responsibility \\
\hline $\begin{array}{l}\text { 1. Economic activity creates problems and } \\
\text { therefore enterprises should participate in } \\
\text { solving them. }\end{array}$ & $\begin{array}{l}\text { 1. The purpose of a business enterprise is } \\
\text { to bring profits to its owners. }\end{array}$ \\
\hline $\begin{array}{l}\text { 2. Employees of the enterprise also create } \\
\text { social groups to which the company is } \\
\text { responsible. }\end{array}$ & $\begin{array}{l}\text { 2. The enterprise has no non-economic } \\
\text { obligations except for those stipulated } \\
\text { by legislation. }\end{array}$ \\
\hline $\begin{array}{l}\text { 3. The enterprise has the necessary resources } \\
\text { to solve social problems. }\end{array}$ & $\begin{array}{l}\text { 3. There is a possibility of a conflict of } \\
\text { interest. }\end{array}$ \\
\hline \multicolumn{2}{|l|}{ 4. Enterprises are partners in economy, just } \\
\hline $\begin{array}{l}\text { like the government and society, therefore } \\
\text { they should strive to meet the socio- } \\
\text { economic and ecological needs of their } \\
\text { partners. }\end{array}$ & $\begin{array}{l}\text { 4. Involvement in social programs allows } \\
\text { enterprises to influence the } \\
\text { environment. }\end{array}$ \\
\hline \multirow{2}{*}{$\begin{array}{l}\text { 5. By accepting its social, economic and } \\
\text { ecological obligations, it acts in its own and } \\
\text { social interest. }\end{array}$} & $\begin{array}{l}\text { 5. Enterprises lack experience in } \\
\text { managing social programs. }\end{array}$ \\
\hline & $\begin{array}{l}\text { 6. All decisions unrelated to the market } \\
\text { game cause a decrease in economic } \\
\text { efficiency and loss of management time } \\
\text { and energy, which reduces economic } \\
\text { efficiency. } \\
\text { 7. It is dangerous for democracy, because } \\
\text { it can lead to the politicization of the } \\
\text { enterprise. }\end{array}$ \\
\hline
\end{tabular}

CSR is based on the statement that enterprises, in connection with their operations, do not bear solely legal and economic responsibility, but are also obliged to undertake such activities that will contribute to the protection of and increase in social standards [8].

Therefore, according to the CSR concept, economic entities are expected to voluntarily accept obligations surpassing the requirements of regulations and conventions that must be respected.

\section{Methodology and Goal of the Paper}

The aim of the article is to present the issues of social responsibility of agribusiness enterprises in the Pomorskie region in terms of their ecological responsibility, indication of selected pro-ecological factors and determination of the relationship between them and the competitiveness of the surveyed companies.

The research was conducted in 2016 using the diagnostic survey method and a questionnaire technique, among 96 intentionally selected agribusiness companies from Pomorskie Province. The questionnaire was addressed to the owners or persons 
responsible for environmental protection in the company, who agreed to participate in the survey. The T-Chuprov convergence coefficient was used to test the significance and strength of the correlation. Its significance was examined on the basis of the $\mathrm{ch}^{2}$ test. The level of significance was assumed at the alpha level of 0.05 .

In carrying out the research, it was assumed that the pro-ecological activities of CSR carried out by agribusiness companies have an impact on the increase of enterprises' competitiveness on the market.

\section{Ecological Aspect of CSR in Pomorskie's Agribusiness Enterprises - Research Results}

Most of the respondents were young people. 15 respondents were below 25 years old, which constitutes $15.6 \%$ of the surveyed respondents. $56.3 \%$ of respondents ( 54 people) were in the 26-45 age group, and another 25 people, or $26.0 \%$ were in the age group of 46-55. Relatively fewest respondents (only 6 people) were more than 55 years old, which is $6.3 \%$ of the respondents.

Among the respondents there were 3 people with middle school education. They were young business owners. The largest number of people -46 had vocational education 34 respondents had high school education. Among the respondents there were also 13 people with college education.

It can be concluded that the persons participating in the study had extensive experience, as most of the respondents had continued their careers for over 10 years.

Due to the company's position on the market, they could choose one of four responses, i.e. leading, developing, stable and declining positions. Only $12.5 \%$ (12 companies) recognized their position on the market as leading, $44.8 \%$ (43 companies) as developing, and $39.6 \%$ (38 companies) as stable. The position of only three surveyed enterprises, according to the respondents, decreases yearly.

Managers and employees must competently understand the idea of corporate social responsibility, because only then can the enterprise be socially responsible.

Table 2. Knowledge about CSR in the respondents.

\begin{tabular}{lll}
\hline Specification & Number & \% of the total \\
\hline Yes & 79 & 82.3 \\
Difficult to say & 12 & 12.5 \\
No & 5 & 5.2 \\
\hline
\end{tabular}

When asked about their knowledge in the field of corporate social responsibility, $82.3 \%$ of respondents answered that they had such knowledge, while $54.2 \%$ even considered it to be large. The knowledge of CSR principles may result from the fact that the answers were given by the owners, managers or persons dealing with environmental problems in small and medium-sized agribusiness companies, who ought to have such knowledge due to their positions. Only $5.2 \%$ of respondents admitted to a lack of 
knowledge about CSR, and $8.1 \%$ did not express their opinions on this issue (see Tab. 2).

More and more owners and managers of agribusiness companies perceive the activity of their company in the perspective of the impact on the natural environment and the company's surroundings. Out of the 96 companies surveyed, more than half $(53.1 \%)$ considered their business activity with regard to the principles of ecology as the priority in the area of CSR. The respondents admitted that ecological problems will not solve themselves, and the damages caused to the environment are punished by financial institutions with high fines.

Table 3. Ecological aspects of CSR in the development of agribusiness enterprises recognized by the respondents as the most significant.

\begin{tabular}{lll}
\hline Specification & Number & \% of the total \\
\hline $\begin{array}{l}\text { Protecting and restoring the original environment } \\
\begin{array}{l}\text { The use of sustainable development principles in } \\
\text { production, processes and services }\end{array}\end{array}$ & 51 & 40.6 \\
$\begin{array}{l}\text { Development and implementation in the } \\
\text { companies of the environmental management } \\
\text { system }\end{array}$ & 38 & 39.1 \\
$\begin{array}{l}\text { Economical management of natural resources, } \\
\text { energy, etc. }\end{array}$ & 57 & 59.4 \\
$\begin{array}{l}\text { Using environmentally friendly means of transport, } \\
\text { i.e. reducing the emission of harmful gases }\end{array}$ & 47 & 49.0 \\
$\begin{array}{l}\text { Monitoring of energy and consumption and } \\
\text { pollutant emission }\end{array}$ & 26 & 27.1 \\
$\begin{array}{l}\text { Having emergency action plans in the event of a } \\
\text { breakdown or accident }\end{array}$ & 13 & 13.5 \\
\hline
\end{tabular}

The respondents considered economical management of natural resources, energy, etc. as the most significant ecological aspect of CSR (59.4\%). Subsequently, the application of the principles of sustainable development in production, processes and services $(53.1 \%)$ and protection and restoration of the original environment (40.6\%), as well as the development and implementation of the environmental management system (39.6\%) (see Tab. 3).

The next question concerned the need for changes in the company regarding the ecological aspects of CSR (see Tab. 4).

Table 4. The necessity to introduce changes regarding ecological aspects of CSR in the company in the opinion of the respondents.

\begin{tabular}{lll}
\hline Specification & Number & \% of the total \\
\hline Yes & 66 & 68.8 \\
Difficult to say & 11 & 11.4 \\
No & 19 & 19.8 \\
\hline
\end{tabular}


In the scope of ecological aspects of CSR, $68.8 \%$ of respondents acknowledged the need to make changes in the company. In turn, $19.8 \%$ of respondents did not notice such a necessity, and $11.4 \%$ of respondents did not comment on this issue (see Tab.4).

Social responsibility in contemporary business affects the changes taking place in enterprises. These changes bring many benefits (see Tab. 5).

Table 5. Benefits from the implementation of environmental aspects of CSR in enterprises in the opinion of respondents.

\begin{tabular}{|c|c|c|}
\hline Specification & Number & $\%$ of the total \\
\hline Achieving compliance with applicable legal regulations & 26 & 27.1 \\
\hline $\begin{array}{l}\text { Reducing the negative impact of the company on the } \\
\text { environment by improving the control, modification or } \\
\text { change of the process of introducing recycling of raw } \\
\text { materials, media and the amount of waste generated }\end{array}$ & 67 & 69.8 \\
\hline $\begin{array}{l}\text { Reduction of fees for using the environment and } \\
\text { environmental fines }\end{array}$ & 61 & 63.5 \\
\hline $\begin{array}{l}\text { Improvement in the company's image and cooperation } \\
\text { with the surroundings }\end{array}$ & 31 & 32.3 \\
\hline $\begin{array}{l}\text { Reducing the company's operating costs by decreasing } \\
\text { the consumption of raw materials }\end{array}$ & 42 & 43.8 \\
\hline $\begin{array}{l}\text { Reducing the risk of breakdowns and accidents } \\
\text { (including environmental) }\end{array}$ & 22 & 22.9 \\
\hline Reduction of the risk of civil and criminal liability & 8 & 8.33 \\
\hline Facilitation of obtaining external financial resources & 13 & 13.5 \\
\hline
\end{tabular}

$69.8 \%$ of the respondents considered reduction of the organization's environmental impact achieved as a result of: improvement of control, modification or change of the process, change and introduction of recycling of raw materials and the amount of waste generated, reduction of fees for using the environment and environmental fines for basic benefits concerning the implementation of ecological aspects of CSR in an agribusiness enterprise (see Tab. 5).

In summary, the analysis shows that:

- 79 enterprises have knowledge of corporate social responsibility,

- 57 enterprises conduct economical management of raw materials and energy,

- 38 enterprises have developed and implemented an environmental management system,

- 51 enterprises apply the principle of sustainable development in production, processes and services,

- 39 companies strive to protect and restore the original environment,

- 67 companies have reduced the negative impact on the environment by limiting the amount of waste,

- 47 agribusiness enterprises use means of transport that reduce emissions of harmful gases to the environment, 
- 61 companies have reduced the fees for using the environment and environmental fines.

The research conducted has shown that the vast majority of enterprises operating in the Province of Pomorskie take responsibility for the effects of their activities on the natural environment and significantly contribute to its improvement.

\section{Ecological Aspect of CSR and Competitiveness of Pomorskie's Agribusiness Enterprises - a Dependency Analysis}

The aim of the analysis conducted was to answer the question: is there a relationship between selected environmental CSR factors and the competitiveness of enterprises from the Pomorskie region. The variable $y_{i}$ was the degree of competitiveness of the surveyed enterprises on the market, taking into account their division into the so-called leaders, developing, stable and declining.

The variable $\mathrm{x}_{\mathrm{i}}$, where $\mathrm{i}=1, \ldots ., 8$, represented the selected ecological factors of CSR, i.e.:

$\mathrm{x}_{1}$ - having knowledge of CSR,

$\mathrm{x}_{2}$ - economical management of natural resources, energy, etc.,

$\mathrm{x}_{3}$ - development and implementation of an environmental management system in companies,

$\mathrm{x}_{4}$ - use of sustainable development principles in production, processes and services,

$\mathrm{x}_{5}$ - protection and restoration of the original environment,

$\mathrm{x}_{6}$ - reducing the negative impact on the environment by limiting the amount of waste,

$\mathrm{x}_{7}$ - use of means of transport reducing emissions of harmful gases,

$\mathrm{x}_{8}$ - reduction of fees for the use of the environment and environmental fines.

The T-Chuprov coefficient was used to test the significance and strength of the correlation. Its significance was examined on the basis of the $\mathrm{ch}^{2}$ test. The level of significance was assumed at the alpha level of 0.05 .

Table 6. Value of the $\mathrm{ch}^{2}$ test and the T-Chuprov correlation coefficient for the $\mathrm{x}_{\mathrm{i}}$ variables.

\begin{tabular}{lll}
\hline Variables & $\mathrm{ch}^{2}$ value & T-Chuprov correlation coefficient \\
\hline $\mathrm{X}_{1}$ & 3.3117 & 0.141 \\
$\mathrm{X}_{2}$ & 3.5994 & 0.147 \\
$\mathrm{X}_{3}$ & 4.1889 & 0.159 \\
$\mathrm{X}_{4}$ & 3.2857 & 0.141 \\
$\mathrm{X}_{5}$ & 3.9224 & 0.154 \\
$\mathrm{X}_{6}$ & 4.2244 & 0.160 \\
$\mathrm{X}_{7}$ & 1.4559 & 0.094 \\
$\mathrm{X}_{8}$ & 3.2119 & 0.139 \\
\hline
\end{tabular}


Research on the ecological aspect of CSR showed that the correlation between the studied traits is significant and the strength of the relationship is weak.

All values of the T-Chuprov coefficient were at a similar level. Two features $-\mathrm{x}_{3}$ (the development and implementation of an environmental management system in companies) and $\mathrm{x}_{6}$ (the reduction of the negative impact on the environment by limiting the amount of waste) have reached the highest values of $\mathrm{T}=0.159$ and $\mathrm{T}=0.160$, respectively. The feature $\mathrm{x}_{7}$ (the use of means of transport reducing emissions of harmful gases) had the lowest value of the $\mathrm{T}$-Chuprov coefficient $-\mathrm{T}=0.094$. The remaining values of the $\mathrm{T}$-Chuprov coefficient ranged from $\mathrm{T}=0.139$ to $\mathrm{T}=0.154$ (see Tab. 6). The research has shown that a number of factors influence the competitive advantage of enterprises on the market, including the researched variables pertaining to the environmental aspect of CSR.

\section{$6 \quad$ Summary and Conclusions}

Changes occurring in the environment of modern enterprises influence the evolution of the main success factors on the market. In addition to the need to compete in the field of prices, technology and organization, it is necessary to present the company as a reliable, trustworthy and honest business partner. In connection with such expectations, the idea of corporate social responsibility was created [9]. Activities in the field of corporate social responsibility are increasingly taken up by agribusiness companies from the Pomorskie region. What is important is the way the company affects the environment or the local community; the investments in the environmental protection are also important, as well as respecting the law. Building a strong and stable position on the market is an important element of competitive advantage. From year to year, the concept of corporate social responsibility is gaining more and more supporters and its importance in the society continues to grow [13]. Corporate social responsibility is based on the enterprise-society-environment cooperation. This dependence means that enterprises strive not only to obtain material and social benefits through deepening the cooperation and a positive contribution to the society, while minimizing the negative consequences for this society and the environment.

The research conducted among 96 Pomorskie's enterprises showed that these companies are aware of the effects of their activities and take responsibility for them. Thanks to this, they achieve measurable benefits. These enterprises have knowledge in the field of corporate social responsibility, they conduct economical management of raw materials and energy, and some have developed and implemented an environmental management system; over $50 \%$ of the surveyed companies apply the principles of sustainable development in production, processes and services. Among the surveyed enterprises there were also those that strive to protect and restore the original state of the natural environment. Furthermore, as many as 67 Pomeranian companies have reduced the negative impact on the environment by reducing the amount of waste, and 47 by reducing the emission of harmful gases through the use of environmentally friendly means of transport. 
The research on the ecological aspect of CSR showed that the correlation dependence between selected pro-ecological factors and the competitiveness of the surveyed companies is significant and the strength of the relationship is weak. It can therefore be concluded that the competitive advantage of Pomeranian enterprises on the market is influenced by many factors, including those that relate to the environmental aspect of CSR.

Acknowledgements. The article was created as part of the project entitled "Contemporary changes in the functioning of rural areas and agriculture in the light of the Common Agricultural Policy of the European Union.” Project no.: BS 53/2014.

\section{References}

1. Chodyński, A.: Odpowiedzialność ekologiczna przedsiębiorstwa wobec interesariuszy. Przegląd Organizacyjny, No. 5, pp. 36-40 (2010).

2. Codogni, I., Szanse i ograniczenia stosowania strategii CSR w polskich przedsiębiorstwach, „Annales. Etyka w życiu gospodarczym”, No. 15, pp. 281-294 (2012).

3. Dąbrowski, T.: Polityka CSR jako element umacniania reputacji, Marketing i Rynek, No. 2, p. 3 (2011).

4. Gagalyuk, T., Valentinov, V., Schaft, F.: The Corporate Social Responsibility of Ukrainian Agroholdings: the Stakeholder Approach Revisited, Systemic Practice and Action Research, vol. 31, Issue 6, pp. 675-698 (2018).

5. Hąbek, P., Szewczyk, P.: Społeczna odpowiedzialność a zarządzanie jakością, Wydawnictwo Politechniki Śląskiej, Gliwice (2010).

6. Jastrzębska, E. M.: Wybrane inicjatywy w ramach koncepcji społecznie odpowiedzialnego biznesu. In: Jeżowski, P. (ed.), Ekonomiczne problemy ochrony środowiska i rozwoju zrównoważonego w XXI wieku, p. 105. SGH, Warszawa (2007).

7. Kryk, B., Koncepcja społecznej odpowiedzialności biznesu za środowisko przyrodnicze. In: Kopycińska, D. (ed.), Teoretyczne aspekty gospodarowania, pp. 199-209. Katedra Mikroekonomii Uniwersytetu Szczecińskiego, Szczecin (2005).

8. Nakonieczna, J.: Społeczna odpowiedzialność przedsiębiorstw międzynarodowych, Difin, Warszawa (2008).

9. Olejniczak, K.:, Wpływ wybranych czynników ekologicznego aspektu CSR na przewagę konkurencyjną przedsiębiorstw działających na terenie województwa śląskiego. Rocznik Ochrona Środowiska, vol. 15, pp. 2840-2849 (2013).

10. Pakulska, I., Rutkowska, M.: Social Responsibility Business as a Modern form of Business Ethiec, Double-blind peer-reviewed proceedings part II. of the International Scientific Conference, Hradec Economic Days 2018,vol. 8(2), pp. 114-126, Hradec Králové (2018).

11. Słupik, S.: Ekologiczna społeczna odpowiedzialność biznesu w strategiach rozwoju firm. In: Gospodarka w Praktyce i Teorii, No. 3 (36), pp. 77-89. Uniwersytet Łódzki, Łódź, (2014).

12. Wielewska, I.: Ecological investment projects in the scope of activity of agribusiness enterprises - selected issues, vol. XV, book 3, p. 374. Roczniki Naukowe SERiA, Warszawa - Poznań - Rzeszów (2013).

13. Wielewska, I., Zuzek, D. K.: Economic aspects of corporate social responsibility and sustainable development in companies, Economic Science for Rural Development Conference Proceedings of the International Scientific Conference, No. 47, 389-393, Jelgava (2018). DOI: 10.22616/ESRD.2018.043 
14. Zuzek, D. K.: Społeczna odpowiedzialność biznesu a zrównoważony rozwój przedsiębiorstw, Zeszyty Naukowe Małopolskiej Wyższej Szkoły Ekonomicznej w Tarnowie, vol. 21, No. 2, pp. 197-207 (2012).

15. Zuzek, D. K., Zvirbule, A.: Corporate social responsibility as a chance for sustainable socialeconomic development of small and medium enterprises in Poland and Latvia. Economic Science for Rural Development Conference Proceedings of the International Scientific Conference, No. 47, 424-432, Jelgava (2018). DOI: 10.22616/ESRD.2018.049. 